\title{
Management and Design of Fiscal Policy Towards Economic Development
}

\author{
Krasniqi Malush, PhD.c \\ Ministry of Finance, Tax Administration- Kosovo, Udhëheqës i Ekipit të Kontrollit \\ Dep. Operacioneve - Ekipi i Kontrollave, Prizren \\ www.atk-ks.org, malush.krasniqi@atk-ks.org/malushi07@hotmail.com
}

Doi:10.5901/mjss.2014.v5n20p990

\section{Abstract}

Based on the fact of economic transition from a planned economy to a free market economy with internal, but external and every day more are more obedient than fiscal policy which defines the state (government) have an orientation of economic development, or determining the direction of development of a country, as well as a determining factor of the withdrawal of foreign investment. Western Balkans almost two decades now being attacked by the reality of transition, and the inability of building sustainable fiscal policies, to make proper orientation, as well as to attract foreign investors (The case of Kosovo). The Western Balkan countries are currently in a similar horizon in this journey, where all states are performance and successive challenges, in the same sectors as in the economic, legal and political, which all make an effort to come out this isolation transitive, towards a light, economic stabilization. Kosovo now has an interest, to begin economic stability, but with a perfect start, economic, with a vision and interest provided by the EU, and the many lessons learned by neighboring countries, that are pass, and have, passed, through these economic phases. Therefore we must be as vigilant in adopting and commitment of making the best economies, the experiences of European and Balkan countries, needs a clear cohesion, and doing some medium and long term policies, the economic path of interest Kosovo, for a sustainable economic development This is a reality that provided us with the opportunity to improve but that can never leave without facing directly. Reforms should be modeled taking into account these special features which I think are very long term:1. Investment security, adequate legislation and security, to be implemented straight with the legislation. 2. Attractive Building (attractive) fiscal policy. 3. Transparent privatization of SOEs. 4. Clear procedures and elimination of public administration through byrokracive. Kosovo can be attractive for foreign investors due to the fact that there is a very young population where the average age of the population is 26 years.

Keywords: Management, globalization, transition, fiscal policy, law enforcement, administration.

\section{The Management of Transition, and Maintain of Economic Stability}

Western Balkans, is a complex community of nations, ethnicities, cultures and traditions, economies on common exchange, and to radical changes in the friendly neighborly relations and contrary to the absurd hatred between them.

\section{Fiscal Policy in Transition Balkan Countries}

Fiscal policy in transition countries in the Western Balkan countries is oriented toward reform modeled on three main priorities: simplification of the tax system, establishing transparency and clear procedures and ensuring that legislation is being implemented in the right way. Tax increases intended to increase budget revenues can often be self-destructive and that public authorities should limit contributions to social security funds, in order to stimulate job creation and development of small and medium enterprises in our country. At the same time, more than a few transition countries have embraced fiscal policy as a possible means to attract foreign direct investment in our country. Bureaucracy and corruption often cited by investors as obstacles to business expansion, in most countries of the Western Balkans. Fiscal policy has its importance and it needs to be designed better in the field of economic benefits in stimulating and building profitable economic sectors.

How important is fiscal policy and tax competition can be illustrated by the success of the Slovak state in attracting the company Hyundai. This example can be seen from two viewpoints. One is in connection with the accession of ten new countries including eight former communist countries in the EU. Tax legislation is one such area. A second perspective about the ability of governments to use fiscal policy in order to encourage more business. Some new countries acceding to the EU are lower taxes to a level such that the older members are talking about "unfair 
competition". The case of Slovakia has set a single quote for income tax (19\%) mimicking the pattern in which the Baltic countries have experimented for years. Corporate taxes have also been reduced in countries such as Poland and Hungary.

Another example Austria, has determined that it must develop similar policies in order to stem a possible capital. Germany and France are arguing that tax competition is reminiscent of competitive devaluations, in which the exchange rates used to improve the competitiveness of exports. Results warn them that would be unprofitable for all Although national fiscal policies represent a wide range of variation within the EU. The European Union and the region with competitive skills with the best in the world in terms of knowledge-based economy reinforces this fear. It may be only a matter of time before the European Commission in Brussels how to deal with the definition of "rules" intended to administer tax competition within the EU.

It is clear for Bulgaria, Romania and Croatia that they simply can not overlook what are their neighbors and that they must simplify and improve their tax systems. The case of Romania, for example, should reduce its contributions to social security in a much lower level. At the same time, these countries need to find ways to keep track of their budget deficits, and find other revenue needed to finance development projects ${ }^{1}$.

Tax competition presents both the opportunity and risks. With lower taxes can stimulate business and, when conditions are suitable, may increase budget revenues. However, if you sit a lot, they can be harmful to budget revenues and could endanger public goods such as infrastructure, education and health care, etc..

\section{Transition in Kosovo}

Starting from the configuration of the new regional economic surroundings, and European-International, and the specific construction conditions of the economic system in Kosovo, the latter should be based on:

- Privatization of SOEs (state);

- Economic liberalization;

- Economic Adjustment under the concept of an open economy and the market;

- Principles of the rule of law;

- Social Justice;

- Trends in the globalization of the economy.

Kosovo, as a small country at the same time as part of geographical Europe, will be directed to the construction of the economy according to a market economy open to European-regional and international, with a prudent regulatory and economic liberalization neighborhood.

Kosovo needs an economic system to creates an environment for the integration of the economy on the region and beyond, stimulating economic cooperation incentive interest in joint investments with foreign partners, need a clearly defined strategy, the transformation property state (social) and private property for the development of entrepreneurship as a development philosophy in all its necessary infrastructure. This enables the creation of a favorable environment for the development of competition and the autonomy of enterprises, including risk category. The role of the state, specifically Kosovo should focus on contemporary macro-economic regulation, to provides economic stability and building development policy. These include: stabilization of the national currency (Euro), the exchange rate, regulation of economic relations with the outside world, construction of regional policy, construction of agricultural policy, environmental and public finances. The operation economic system, should support in democratic institutions, liberal democracy and open society as well the internationalization of the economy and society in Kosovo. The transition is known to be transformative process of profound dimensions of a social system, through which the system passes into a new structure, which provides an efficient and effective higher. To achieve these performances, solidifying should stimulate changes in all subsystems of the social system, and above all in the political system, economic system and the education system as one of the most durable investments a country's development. This type of transition can not be process, governed by the case. This means that the need to build a strategy and mechanisms by which the need to overcome these obstacles.

On the specifics of transition in Kosovo:

Political situation: install the occupying power, and movement branched, massive and for freedom;

- adverse economic structure, with state-occupied, watched and technological backwardness, and economic infrastructure damage that match with a typical colonial action;

\footnotetext{
${ }^{3}$ wwwpoltikafiskale.com autor Kujtim Serxhanaj E publikuar ne : Free Human Rights Booklet, Raider Publishing,Yi Jing-Book of Changes, KirtasBooks.com, Rare Bibles / Leaves, Rarebookreview.com
} 
- Level of development and the significant social problems;

- Private Initiative relatively developed but is under pressure environment in which

- acting, experiencing conceptual crisis and stagnation in its development;

- Diaspora quite large and weighty economic and socio-demographic;

- Apparent need for technical assistance.

Transition in Kosovo started in the late 80s, ie the movement for freedom and democracy .. Approximately $25 \%$ of Kosovo's population found in Western Europe and

U.S., the majority without adjust status but were a strong pillar of survival and horns in postwar processes. Kosovo now has open doors for exiting the lengthy transition that was not active. To the opinion, that is for us to move these doors right progressive integration of development, that open horizons of development and improvement of social and economic life, bringing capital goods from foreign direct investment in Kosovo.

We need to be more unique, hospitality host to foreign investors, short-term policies should clearly build attracting these investors, and much more to strengthen state-building, strengthen investment in justice, and in the preparation of economic experts , for the purpose of suckling to foreign investors, for the good of the country and the region. We may have a chance of creating capacity, and invest together with our friends, who have to be aligned inters development policies in the Western Balkans region. Where these investments should be seen as vital and attractive to the people and land of Kosovo. We need to be more open eyes at adaptation and acceptance of regional and European policies, in order to be more closely with global and international journeys².

\section{Relations with the Financial Market and Banks}

Financing as economic conditions: capital market, interest rates and inflation restrict the flow of funds, and determine the pace of economic recovery. During periods when the percentage of low bank interest, consumers are more willing to take credit for the purchase of goods and services that the market offers. In these circumstances the business of buying cheaper cost of capital for its expansionBut banks in Kosovo have they helped economic development? I think a little bit , because the disclosure of financial interest loans have a very high interest rate which ranged from $11.5 \%$ to $13 \%$ annually, and to surprise most of the bad loans in Kosovo are the lowest compared to other countries in the region. but why does this happen? Banks called in that it is treated as a threat because the country after the war situation, but suspicions are that commercial banks in Kosovo have agreements among themselves to keep interest rates higher. Businesses enter into relationships with banks to obtain loans with different terms.

For loans granted, the bank wants to get interest on the money while owning businesses in their bank accounts were paying them an interest rate.

Giving credit is subject to a lot rigorous rules wall, banks require repaying loans on time previously agreed at the time of the sinking of the loan in accordance with all interest rates. The problem of the cost of capital is also associated with the level of inflation, because inflation, if it is high, affecting the commercial capital in three main aspects;

- Enhance needs to borrow, since the value of stocks and income grow along expected inflation;

- Increases, interest courses, being so expensive loans;

- It is usually accompanied by government reactions that lead to the tightening of lending.

Therefore, usually for small businesses, this is discriminatory, since they are not well prepared to compete with big businesses, for delivery of funds that can be lent, always coming and reducing. From the explanation given above, we can see that businesses are always under control and the threat of the bank, while a business may enter into a relationship, not just a bank but can enter into relationships with several banks simultaneously, but businesses that not familiar with the bank's financial system conditions of market economy, are susceptible to failure.

Businesses except financial relationships with banks, financial develop the relationship between them, such as buying and selling liquidation payments, and competition relations.

Every business, some point, has a number of products and services in the market, which offer products and services with manufacturers and other businesses. Similarly, banks and financial brokers are in competition with each other, interest rates, and withdrawal of deposits from businesses and citizens.

As a rule or principle aim of any business, is seeking to spend less and get more, this principle is reflected all commercial businesses.

Profit is linked to the cost of production and cost of sales, business wants to buy the much cheaper price and sell

\footnotetext{
2 Selman .Selmani 2006.Prishtinë.,Globalizimi dhe tranzicioni..Servet Pellumbi Analizë Tiranë, Nimani.A,Menaxhimi i financave publike Prishtinë 2010,f25-33.
} 
at the highest possible price, but the balance of market competition as in the case of sale as well the case of acquisition, this fact shows that financial management should study very carefully the level of supply and demand in the market as well as other elements surrounding business. Management must recognize market, have basic knowledge of the other competitors, who belong to the same branch or areas, should know who are the main competitors compete with what basis, who are potential future competitors etc..

Competitive position of businesses depends on many factors, among which are veqojmë;

a) the quality and characteristics of the product, b) established relations with customers and suppliers

c) status and social position eklientëve and environment where business operates, d) financial strength and financial resources, d) strategic partners, e) cultural factors, f) social factors, and g) psychological factors.

Businesses alongside financial relationships with banks and businesses, have financial relationships with the employees themselves, and for the importance of belonging to a very large extent. The management of human resources, which are owned enterprise including; planning, recruitment, selection, training and development and motivate employees to perform specific tasks, all these actions are closely related to financial management.

Of particular importance for businesses, supply, quality and price of labor. Many developed countries have transferred production or a part of them in other places outside the country of origin due to cheap labor and abundant.

Scientific experiences have shown that the most effective motivation is motivation through payroll and insurance of participants solving business problems. Another important action to take, and to which the management of the company, must show constant care is the relationship with customers, because the essence of the business lies the relationship between businesses and consumers, or buyers (clients) to itself. SUCCESS business depends on the stability of its customers, which means that it has secured a stable market for the products and services infections. The goal of business is to continually increase the number of its clients, using advertising Steven Fielding, economic push from, different promotions etc.., These businesses take actions to assimilate new customers and turn them who has lost. Keeping existing customers and gaining new clients, usually associated with acceptable prices by them. Advertising to consumers besides, different promotions etc.., Affecting many external factors, which do not depend on such business; competition, network distribution, tax policy measures, regulations and government policies. At the present time many businesses are practicing selling products through intermediaries, not themselves be present in the market, so the role of the intermediary is becoming increasingly important ${ }^{3}$.

\section{Globalization and Its Impact on Transition}

On the issue of globalization and the global market economy, come to terms with lower cost of the workforce, the efficiency loss of national fiscal rules, the law and the weakening of the State classic idea that sovereignty, then we have the emergence of China and India on stage as powerful new actors in the global economy which make competition, the U.S. economy and the European economy, so various aspects of globalization, where busy right spot in the media, nationally and internationally. These technical changes, contain a potential new economic globalization, for example. various services from Asia to Europe, Africa, in Asia, Europe, to China, India, etc. All these are results of economic globalization (openness of the global free market).

But when are the globalization of the economy, we need to understand that some enterprises may become insolvent, because they are not prepared for them Following the trend of world development, as for the quality of the products, as for the cost of the product, but also by Not preparing adequate staff (human factor). Globalization is the greatest challenge of the 21st century, for countries in transition and challenging which requires great care, state governments in maintaining local economies. What is required by the state, the purpose of an easier the integration and always keeping local enterprises? I think, required very careful change, fiscal policy in the construction of the purpose of preserving the local products, but always in the trend of free market development. Globalization in many cases seen as strengthening and deepening the institutionalization of production, exchange and development in general, they have determined that the process of spreading global system, which results in process A physical presence, and global development models. In the early stages of globalization, when states eliminate customs barriers, and get involved in a free market, many local private businesses go bankrupt, because of the strong competition, and their inability to dealing with this competition. Globalization is indicative of the fact the system, where integration is done in different ways, as a society with different civilizations, and bringing different cultures, regardless of their properties at all authenticEconomic integration is today central issue in contemporary international relations, almost any government of any country attaches

\footnotetext{
3 Prof.dr -Isa Mustafa Menaxhmenti financiar -Prishtinë 2008-f,26-31. Sqarim: Nëpër tekst ka nderhyrje nga autori për qellim të pershtatjes me temën
} 
special importance to international relations, particularly in developing countries or countries in transition, as is the case of Kosovo. But how can you quickly integrated into a global market, and how to build a truly free market, where no customs barriers exist, and many other barriers and bureaucracy, can we see this in the coming years, since for now we cannot say that we have legislation nor the fiscal policy integration, which will be able to confront the global economy or globalization.

The successful integration is one of the fundamental generators of economic growth in the context of integration achieved with a high mobilization, and flexible workforce because labor force pushes and guides the process of social transformation towards technological development.

Well acquainted, that countries which have shown that faster we embrace European integration policy, (because Europe is the main driver of global economic growth) have achieved a rapid economic development. Many markets in former socialist countries, which have had an economy controlled by the state, are destroyed and are integrated in the free market system of the European union. Analysis of many economic experts have indicated that mobile growth and development a transition state, is undoubtedly recapitalization of existing technologies, developed the industry average for the country, which enabled rapid technological transformation and successful presentation in international markets (e.g, Czech Republic, Hungary, Slovenia, etc.). ${ }^{4}$

\section{Social Implications that Globalization Causes}

Globalization creates about business outside the State of a country, spread innovation and develops, new types of social relations, at great distances, most recently this happens, thanks to the development of information technology, transportation and cheap communication between people feature. Dissemination of information to diverse, has influenced the world seem smaller and more accessible, which in turn increase the njrëzve personal aspirations, but if these people's aspirations or goals can not be achieved, then we have as a result of frustration and grievances of the people. For example, it is difficult to believe that the Chinese can reach the U.S. standard of living, which do not distort seriously the current balance of resources and productive capacities. Efforts to achieve such a vital standard, with globalization as the process, of course speed achieved by the fulfillment of their opportunities, because globalization together with the phenomenon of aging societies, most advanced, which is creating some interesting phenomena. In societies that are aging, is increasing demand for new labor force, while on the other side of globalization are spread universal values, values which most people, of all countries, more and more are adopting as a way organizational behavior and western life. Generally people the western cultural phenomenon, has been making major and ever-closer.

Seeing these two trends, which is growing by the day, the encouragement of immigration to people from underdeveloped countries and developing countries to developed Western countries in search of a better life, and more organized. With this problem Kosovo also faces immigration, due to political uncertainty, low living standards, slow economic growth, many other factors, are driving the youth of Kosovo beset western countries, often risking trips and crossings border illegally, and with a fairly high risk.

But even though immigration is becoming more attractive every day, even in cultural view is acceptable and easy, but the development of communication technology is enabling the process of assimilation, to be slower compared to historical periods. Also communication with the homeland, the family is becoming every day more easy, because this is the Internet enables, but also cheap ticket prices for travel from different airlines.

From all this change, see that society is moving towards building a new identity as a process of personal maturity important for people, and is associated with belonging to social groups, organizations and associations of social communities, in place where they live.

Identity is social structure, which is constructed by history, geography, biology of productive and reproductive institutions, by keeping the collective opinion and personal preconceptions, by force apparatus (state) as well as by religion. Man during these global trends, meets different people, different cultures, and in the course of construction of identification operates, also a new dimension of social network. Now action is to create a multiple identity, national identity and the transition from the State, the right global identity, the process which the government and policy (different countries but also to the government of Kosovo) will be completely new seating requirements. If we see that globalization has an impact on the social order, the states and the development of technology (the Internet) is feeling overshadowed

\footnotetext{
${ }^{4}$ Adrian Civici-Globalizimi...Ante portas - 2012 f,109-146, Adrian civici - Kriza Financiare apo globale - 2010 f, 19-72, Nëpër tekst ka nderhyrje nga autori i temes, ne rastet e krahasimit e ndikimit te krizes finaciare në Kosovë.
} 
national societies of people from different countries. ${ }^{5}$

\section{Conclusion}

The study presents the impact of fiscal policy on economic development of a country. Where we say that fiscal policies, which relate directly to the economic development of a country, in our case of Kosovo. But the tax administration of Kosovo, which is authorized to oversee and implement fiscal policy tax is not coherent to verify businesses, which have state tax credit in. Therefore, Ministry of Finance, should change the law, and the legal rights of loss carried forward for seven (7) years, to reduce in two or three years, because I think that will be given direct results in revenue. As recommendations, we can say that stakeholders in Kosovo leaders must begin to do the escalation of VAT (Value Added Tax), for things such as food, oil, bread, flour, sugar, sold, etc. So basket Daily family. State intervention economic flow through fiscal policy, justified by regulations made in terms of eliminating the phenomena that impede the preservation of the general welfare of society. However, care should be taken during any increase or decrease the tax rates for taxes present opportunities but also risks. Can lower taxes to stimulate business and, when conditions are suitable, may increase budget revenues. However, if you sit a lot, they can be harmful to budget revenues, and could endanger public goods such as infrastructure, education and health care, etc.. Some arguments have shown that efforts to make sweeping changes in the tax system, were more successful than those that have specific provisions modified. Seeing these theories, as well as many different theories of thinkers could conclude that any tax reform must be accounted for best of the best strengths, and weaknesses, which is difficult for bears in itself every tax reform and determination required for the viability of law.

The second conclusion - has to do with the privatization of state-owned enterprises.

To successfully develop the privatization process should ensure: public development (transparent), with what to avoid possible misuse, sale of assets under the price of the market, through open market value and competitive development programs business can neutralized the negative effects. Where I think that privatization in Kosovo should be developed on the basis of competitive programs (manufacturing or commercial) and the open market value. Information has an important role, which creates conditions for massive participation of the subjects in the privatization process and reduces the chances of double standards. Maximizing the price is very important principle, because it means the elimination of privileges and buyers, enabling free and fair competition for all participants and promotes the interest of as many buyers. State intervention in economic flow through fiscal policy, justified by regulations made in terms of eliminating the phenomena that impede the preservation of the general welfare of society. These phenomena associated with imperfect market action: protecting the poorest strata of society, creating jobs, avoiding monopolies and increase competition proper, fairer redistribution of wealth, and others.

Fiscal policy constitutes a component of state economic policy, which is used for macroeconomic purposes, to influence the level of product, employment and prices.

Restrictive fiscal policy, applied to close the gap of expansion, so that influence the decrease of aggregate demand through public spending cuts.

While the recession gap closes through fiscal expansion, increasing public spending to influence the growth of aggregate demand.

\section{References}

Robbins \& DeCenzo. "Basics of Management Concepts and basic applications", Tirana 2011, translated by Perry Rezarta llia Kristo. "International Business", Tirana, 2004.

Bardhyl Ceku, Arjan Abbas Semiha Loca. "Basics of Marketing", Tirana, 2010.

Liliana Elmazi (Billa) and purple Hysi. "Basics of Marketing", Tirana, 2008.

Adrian Civici. "Globalization ante Portas", Tirana, 2009

Salman 6.Bedri. "Globalization transition and integration". Ljubljana, Pristina, 2006.

Adrian Civici. "Financial crisis, or global", Tirana, 2009.

Musa Limani. "European Economic Integration", Prishtina 2008.

Sabaudin Komoni. "Public finances", Pristina, 2008

Selman Selmanaj. "Globalization and transition", Prishtina 2006.

Isa Mustafa. "The Financial Management", Prishtina 2008

${ }^{5}$ Dr.Sc Bedri Selmani- Globalizimi-tranzicioni dhe integrimet (refleksionet në Kosovë) f,159-197.Botues Albanica dhe Zenith Lubjanë-

Prishtinë 2006. Sqarim; Nëpër tekst ka nderhyrje nga autori i temës, për qëllime te përshtatjes. 
Malush Krasniqi, "Corporate Albania the past, the present and the future" International Scientific Conference November 9-10, Tirana 2012.

Malush Krasniqi. "ICHSS2013" (international Confrernce on Human and Social Sciences) as international scientific conference 20th 22.Shtator.Romë Italy, 2013.

Malush Krasniqi. "The staen, Society and Law: Human Right's Challenges in Albania" International scientific conference "March 16-16, Tiranë2013.

Archive CBK (Central Bank of Kosovo) Pristine Financial Statements 2008-2013.

Archive TAK (Tax Administration) Revenue from 2008 to 2013.

Archive Kosovo Customs revenues from 2008 to 2013.

Legislation Tax Kosovo Pristina TAK-publisher in 2010. 